\title{
¿Difusión de ideas subversivas? La condena de los Borbones hacia la pedagogía probabilísitica de los jesuitas
}

Disseminatin of subversive ideas? The Borbons's censureship towards jesuit's probabilist pedagogy

Carla Maranguello*

Resumen: En el marco del regalismo borbónico con Carlos III, la expulsión de América de la Compañía de Jesús en 1767, junto con la crítica a sus métodos de enseñanza mediante el probabilismo, se basó en la desconfianza hacia la flexibilidad presente en la concepción ignaciana de la educación, patente en la Ratio Studiorum y las Constituciones de la Compañía de Jesús, que delinearon la enseñanza religiosa hasta la expulsión. A su vez, el impacto de dicha concepción en las imágenes, que se consideraban fundamentales para el adoctrinamiento, permitió la inclusión de elementos de la religiosidad andina, como se observa en la ornamentación arquitectónica de las iglesias doctrinales de Juli (Chucuito), desarrolladas entre los siglos XVII y XVIII.

Palabras clave: jesuitas- probabilismo- Borbones- religiosidad- iconografía andina.

\begin{abstract}
In the context of Bourbon regalism with Charles III, the expulsion of America from the Society of Jesus in 1767 with the censorship of its methods of teaching through probabilism, was based on the distrust of the present flexibility in the ignatian

\footnotetext{
* Instituto de Teoría e Historia del Arte "Julio E Payró"/UBACYT. Facultad de Filosofía y Letras. Universidad de Buenos Aires. E-mail: carlamaranguello@hotmail.com
} 
conception of education, which is evidenced in the Ratio Studiorum and the Constitutions of the Society of Jesus, which delineated religious teaching until expulsion. In turn, the impact of this conception on the images, considered fundamental for indoctrination, allowed the inclusion of elements of Andean religiosity, as seen in the architectural ornamentation of the doctrinal churches of Juli (Chucuito), developed between the XVII and XVIII.

Keywords: Jesuits - probabilism - Bourbons - religiosity - Andean iconography.

Recibido: 15 de mayo de 2017.

Evaluado: 24 de junio de 2017. 


\section{Introducción}

A partir de la mitad del siglo XVIII, el Estado borbónico con Carlos III a la cabeza, llevó adelante una serie de reformas en América, mediante una doctrina regalista, esto es, aspiraciones de la monarquía a ejercer la autoridad regia en todos los terrenos, sin restricción. Entre esos terrenos, la iglesia fue puesta en el centro de la cuestión, ya que era la institución que mayor influencia tenía, limitando muchas veces incluso el poder del estado. Durante el gobierno del virrey Amat (1761-1776) se llevaron al extremo las medidas regalistas, de las cuales la más representativa fue la expulsión de América de la Compañía de Jesús en 1767 y la crítica a sus métodos de enseñanza mediante el probabilismo, que daba lugar a cuestionamientos que colisionaban con los intereses de la corona, y que se consideró de un tinte moral relajado. Por otro lado, en un afán ilustrado de conjugar la fe con la razón y en búsqueda de una religiosidad más austera, se rechazó una utilización de la imagen de tradición barroca, lo que impactó contundentemente en el desprecio por la religiosidad autóctona, punto donde también se atacó a la Compañía, cuya utilización de la imagen exploraba todas las potencialidades persuasivas barrocas de herencia tridentina. En este sentido, en la concepción jesuita de la educación, patente en la Ratio Studiorum [1599] 1616 y las Constituciones de la Compañía de Jesús [1491- 1556], que marcaron los lineamientos para la enseñanza religiosa hasta el momento de la expulsión, puede observarse cierta flexibilidad apoyada en planteos de carácter probabilista, lo que impactó directamente en la concepción de las imágenes que se consideraban fundamentales para el adoctrinamiento, permitiendo la inclusión de elementos de la religiosidad andina, como se observa en la ornamentación arquitectónica de las iglesias doctrinales de Juli (Chucuito), desarrolladas entre los siglos XVII y XVIII.

\section{El Probabilismo y su repercusión en América}

El probabilismo fue un sistema moral vinculado con la renovación de planteos escolásticos que se produjo durante los siglos XVII y XVIII y que consistía en la contrastación de opiniones probables acerca de lo que una persona debería hacer en una situación determinada, cuando no se posee un conocimiento verdadero e indiscutible de su deber moral. Para resolver aquellos casos en que no hay seguridad absoluta sobre la justicia de una norma moral o legal, con la sola presencia de la duda, siempre se tienen por lo menos, dos opiniones probables y opuestas (Bacigalupo, 1999). ${ }^{1}$ No obstante, una opinión probable debía estar apoyada en una razón o fundamento sólido, no debiendo derivarse de ella ningún absurdo, y no siendo opuesta a la razón, ni a la Iglesia. Por otro lado, uno de los criterios para definir el estatuto de la opinión se basaba en accionar a través de la conciencia, es decir, privilegiando una aproximación subjetiva que brindaba la posibilidad de autonomía de la razón práctica y libertad individual. Así, el probabilismo brindaba la posibilidad de analizar las acciones morales en circunstancias puntuales, sacando los juicios morales del plano epistemológico (regidos por la evidencia) al

\footnotetext{
${ }^{1}$ Según Ballón (2008) se podría hablar de una suerte de primer probabilismo surgido en la Academia Griega tardía, como opción intermedia entre dogmatismo y escepticismo, donde se sostenía la imposibilidad de una certeza absoluta del conocimiento, lo que no implicaba el escepticismo, sino sólo un conocimiento aproximado.
} 
plano de las opiniones, ya que si los juicios morales no conllevan certeza intrínseca, ésta no podía sustentarse en la obligatoriedad de la ley (Ballón, 2004).

En Europa, este sistema fue cuestionado por Blas Pascal (1623-1662) entre otros, debido a sus planteos de libertad del sujeto moral frente a la ley y en especial por la distancia establecida entre la verdad moral y la verdad objetiva. Por otro lado, al asociarse con la inobservancia de la ley y el desconocimiento de la autoridad real, fue señalado como peligroso para la moral cristiana y promotor de laxismo, acusaciones que fueron trasladadas al Nuevo Mundo con más énfasis (Martel, 2005). Para alejarse de estas acusaciones de laxismo, donde todas las opiniones serian igual de probables, los probabilistas distinguían entre dos clases de motivos, los intrínsecos, que son aquellos que convienen a la naturaleza de las cosas y los extrínsecos, que apelan a la autoridad de reconocidos estudiosos (Ibídem; Ballón, 2008). Todas estas consideraciones, abrieron discusiones en torno a la primacía del Estado o a la ley por un lado, y en torno al individuo y su libertad por el otro (Bacigalupo, 1999).

En América, este sistema fue sostenido y utilizado por los jesuitas. No obstante sus orígenes doctrinarios pueden ubicarse en la interpretación del Dominico Bartolomé de Medina en la Summa de casos de conciencia (1580) en donde refiere a una cita muy evocativa de Santo Tomás de Aquino (...) «me parece que, si una opinión es probable, sea seguida, aunque la opuesta sea la más probable» (...) (Martel, 2005, p. 18).

La contrarreforma en la Iglesia católica en España a mediados del siglo XVI, fue el vehículo para conservar la tradición medieval escolástica, que se convirtió en la base de justificación legal y ética en Europa y América. ${ }^{2}$ Algunas órdenes religiosas como los dominicos y jesuitas, actualizaron el pensamiento aristotélico y tomista, en armonía con los avances científicos del SXVI.

Para la escolástica tradicional, la normatividad se sustentaba en el derecho natural o divino, lo que suponía la existencia de un orden cósmico jurídico o moral, cuyo motor principal era Dios. El poder divino era entregado al monarca para que gobierne bajo el consentimiento del pueblo, y en caso de llevar adelante una ley injusta podía ser desobedecida. Víctor Peralta Ruiz destaca la figura del jesuita Francisco Suárez (15481617), quien a partir de estas ideas de tradición escolástica, señalaba que la potestad le era conferida al monarca mientras fuese aceptada por la totalidad del pueblo, y por lo tanto el poder regio tenía límites que no podía transgredir. A estas ideas, el jesuita añadió las doctrinas del regicidio y tiranicidio. Es decir, cuando se creaba una situación donde el monarca violaba el bien común, el «tyrannus a regimine», el pueblo podía acudir a sus derechos a la rebelión, por lo que la resistencia pasiva e incluso violenta estaba legitimada si el soberano se convertía en tirano. A su vez, la noción de pactismo, el «pactus traslationis», contemplaba la vuelta de autoridad al pueblo en caso de incapacidad transitoria por parte del soberano para ejercer poder (Peralta Ruiz, 1996, p. 7071). ${ }^{3}$ La fórmula lex dubia non obligat - cuando hay duda respecto de la ley, no hay

\footnotetext{
${ }^{2}$ En esta época se hablaba de "segunda escolástica". Debe considerarse desde el principio que la escolástica medieval y moderna no fue una escuela de pensamiento homogéneo ni un "ismo", sino un fenómeno cultural complejo que recogió múltiples influencias de diversas doctrinas teológicas y filosóficas (Bacigalupo, 1999).

${ }^{3}$ Peralta Ruiz, no hace referencia al probabilismo, sino a la influencia del escolasticismo en diferentes doctrinas que surgieron desde el siglo XVI en América, como el criticismo de los franciscanos (En espe-
} 
obligación- dejaba en claro que era posible la libertad ante la duda sobre la licitud de una determinada acción (Bacigalupo, 1999).

Estas teorías de Suárez, fueron impartidas e interiorizadas con éxito desde muy temprano en espacios de influencia jesuita, tanto en los colegios de caciques donde acudía la nobleza, como entre los indios del común establecidos en las misiones. En las instituciones jesuitas de las zonas rurales por ejemplo, estas nociones de pactismo y regicidio tuvieron impacto en el comportamiento de los caciques indígenas. Los caciques asumían el logro común como resultado de la aplicación de leyes naturales y positivas, contribuyendo a su vez, a preservar representaciones que referían a la tradición nativa:

la razón de esto residió en que, en la pedagogía escolástica, los jesuitas impartieron también la idea de que a cada nación o comunidad le corresponde un cuerpo individualizado con su propia historia y tradiciones (...) su afán por interiorizar en los caciques el principio del pactismo como base de la concordia entre repúblicas de españoles e indios, les llevó a sugerir que cualquier falta a la misma debía considerarse como un acto de herejía. Tal razonamiento chocaría directamente con los principios del despotismo ilustrado (...) (Peralta Ruiz, 1996, p. 73).

Asociado a Suárez y sus ideas, el escolasticismo alcanzó mayor influencia en Perú, con la obra del jesuita Diego de Avendaño (1594-1688), en su Thesaurus Indicus (1688) (compuesto de seis tomos), quien hizo una interpretación desde la perspectiva de Suárez del origen pactado sobre la base del acuerdo natural entre el monarca y la comunidad americana, actualizando a su vez el pensamiento tomista dentro del contexto peruano (ibídem). Avendaño formuló una ética probabilística del estado teocrático para la regulación de relaciones intersubjetivas, siendo las discusiones en torno al trabajo obligatorio de los indios en las minas, uno de los casos más conocidos, donde el jesuita deja clara su adhesión al probabilismo, argumentando que el trabajo en las minas implicaba esclavitud, lo que era adverso a la naturaleza del indígena. Destaca Ballón que su opinión se basaba en argumentos sobre la naturaleza del asunto (intrínsecos) y también en argumentos de probabilidad extrínseca (por ejemplo inconvenientes a la vida y salud de los indios), a diferencia de la de sus oponentes que se basaba sólo en argumentos de autoridad (probabilidad extrínseca). El argumento de autoridad en este caso sería una opinión probable sobre un acto que dependía de las circunstancias contextuales, por lo que la disposición de la autoridad en torno al trabajo en las minas, sería aceptable sólo provisionalmente hasta encontrar una solución más acorde (Ballón, 2004). ${ }^{4}$ De la misma forma, Avendaño aborda la cuestión del pago de aranceles que se hacían en las misas, que fue un tema generador de serios conflictos en los pueblos indios. ${ }^{5}$ Haciendo refe-

cial el de Fray Isidoro de Cala y Antonio Garro) y las diferencias con los planteos de algunos jesuitas como Francisco Suárez.

${ }^{4}$ Ballón toma una frase de Muñoz García (2003) que coincide en algún punto con las discusiones que abría el probabilismo; el proverbio popular de origen colonial: "la ley se acata, pero no se cumple".

${ }^{5}$ A fines de 1770, la administración borbónica estableció la sanción de un nuevo arancel eclesiástico que reducía el costo de las fiestas, los ricuchicus y estipulaba el carácter voluntario de las oblaciones, que los curas doctrineros se negaron a reconocer (Serulnikov, 2003). El autor analiza un conflicto entre indios y curas de la doctrina de Carasi, como ejemplo de este fenómeno. 
rencia al probabilismo y citando a Francisco Suárez en relación al derecho natural y divino, además de otras voces autorizadas como el probabilista Castro Palao, el jesuita argumenta:

Los indios no están obligados a pagar las oblaciones que se hacen en las festividades en el ofertorio de la misa, aunque parezca haber costumbre de ello. Se prueba lo primero por la opinión común que sostiene, con otros (...) el padre Suárez (...) no hay ninguna obligación de oblaciones, ni por derecho natural, ni divino, ni eclesiástico (...) lo referente a la costumbre, puede probarse, en primer lugar por la doctrina de graves doctores que sostienen que la costumbre respecto a las oblaciones no es obligatoria en el fuero de la conciencia, pues habiendo sido estas voluntarias desde su comienzo y así continuadas, de ahí no puede surgir un título oneroso (...) también el padre Castro Palao confiesa que es probable, hacia lo que se inclina mayormente, afirmando que la opinión contraria sólo es probabilísima debido a la autoridad de los doctores. (Avendaño, 2009, F. 485 y 459 , p. 266)

Finalmente tanto para Avendaño como para Suárez, la posesión de las Indias por parte de la corona española era tal por haber sido legada por el Papa, "es claro, porque fue concedido a nuestros reyes no mediante alguna usurpación, sino por la liberalidad de los pontífices, según consta por Bula de Julio II (...)” (Avendaño, 2009, II-70, p. 394) y por ello incluía sólo el territorio y no a las personas, "Su dominio era a fortiori - de hecho y no de derecho - y sólo sobre las tierras, no sobre las personas, no pudiendo someterlas a esclavitud" (Ballón, 2008, p. 41). La propiedad de las personas en este caso, recaería en el pontífice y el derecho se creaba sólo cuando el Papa se lo otorgaba a los reyes (y estos a los conquistadores), creándose una suerte de obligación natural de reciprocidad a los servicios recibidos (Ballón, 2008, p. 41).

Según Ballón, Avendaño es un buen ejemplo de que las reflexiones filosóficas que se desarrollaron en Perú colonial, no fueron una mera repetición de los aspectos retóricos de las teorías escolásticas medievales, sino un producto genuino que surgió de la reflexión crítica de los pensadores que se enfrentaron a las formas de vida novedosa de las comunidades locales, para lo que debieron formular categorías acordes. Por otro lado, expuesta en sus concepciones principales, se ve la razón por la cual esta doctrina moral fue acusada de subvertir el orden, ya que además de recordar las obligaciones del estado teocrático, se interesaba por los asuntos que originaban protestas y revueltas (trabajo en las minas, relación de los indios del común con los caciques, pagos de impuestos, posibles abusos), en un contexto donde la amenaza de rebeliones indígenas siempre estaba latente.

\section{Probabilismo y adaptabilidad religiosa en la missionalia jesuítica}

La educación de los jesuitas se orientó a dos grandes campos de acción. Por un lado, los pueblos de indios, esto es, las reducciones que llevaron adelante un control de las formas de vida del indígena mediante la enseñanza de la doctrina, junto con escuelas de primeras letras y donde la población era mayormente indígena y mestiza. Por otro lado, los grandes centros religiosos urbanos y colegios mayores en barrios cercados de poblaciones no españolas, donde se podían controlar expresiones culturales mixtas, entre criollos y mestizos y a los hijos de caciques que asistían a los colegios mayores.

71 Carla Maranguello. ¿Difusión de ideas subversivas?. La condena de los Borbones... 66-85. 
La situación de los jesuitas alcanzó mayor estabilidad hacia el siglo XVII, ya que gozaban del apoyo de Felipe III, el virrey Esquilache era pariente de Francisco de Borja, y en Lima tenían la simpatía del arzobispo Lobo Guerrero, en especial por su participación en las campañas extirpadoras. Para esta época, tenían el control de estudios superiores de gran parte de la sociedad española, criolla y de la élite indígena, en sus tres casas de Lima y en el colegio de San Bernardo en Cuzco. Retomando el príncipe de Esquilache los planes de Toledo, en 1620 se fundó el colegio de San Borja, que fue el más influyente, ya que tuvo un programa a favor de los indios que tendría larga vida y muy diversos continuadores. Al mismo tiempo fundó la casa de reclusión para hechiceros de Santa Cruz en el cercado de Lima donde existía el colegio del Príncipe desde 1918. En 1620 Esquilache escribía al Rey:

Aunque todos los indios son bautizados es sin duda por falta de enseñanza y exemplo de sus curas, están la mayor parte en su antigua infidelidad, cometiendo muchos y graves pecados así de idolatría como de hechicerías supersticiones y trato con el demonio que se les aparece muy de ordinario (...) en cuyo remedio se hicieran las misiones de la Compañía (...) también se han hecho los seminarios y reclusión que en otra carta doy cuenta a VM" (Alaperrine Bouyer 2007, p. 60)

Sin dudas, la universidad fue la institución educativa que representó la mejor forma de canalizar a los grupos dominantes y lograr la adscripción de los sectores criollos emergentes, ya que estaba ligada con los colegios mayores y seminarios, y era el punto en que la educación se relacionaba con el poder de la sociedad, donde se gestaba la libertad de pensamiento y una perspectiva crítica hacia las políticas de la corona. La Compañía de Jesús, que regenteaba muchas de estas instituciones, estaba inmersa en estos debates. No obstante, también los colegios principales de las ciudades, así como los colegios de los pueblos de indios, eran espacios en donde surgían planteos sobre las desigualdades sociales. La amenaza que representaban los curacas educados que tenían monopolio en la administración y control de cajas de censos, así como protagonismo en los pleitos con doctrineros, y sobretodo la influencia en los indios del común, no escapaba a las autoridades (Glave, 2013). Esta situación era percibida también por sectores influyentes del clero secular, que veían peligro en la educación de los líderes indígenas. En referencia a la destrucción de pueblos de indios, el Obispo cusqueño Fray Fernando de Vera escribe al Rey en 1635:

convendría mucho sacar a estos caciques destos colegios y que la plata que en esto se consume, se aplicase en otra cosa más útil (...) en ellos no aprenden la doctrina que los Padres de la Compañía enseñan sino malicias y pecados, a que su natural le lleva en que salen todos tan ladinos que en volviendo a sus pueblos son demonios y desdeñados de vestir como los indios (Glave, 2013, p.79).

Había conciencia de que tanto en los colegios de las grandes ciudades como en las reducciones, la educación era un puente para conocer y entender el funcionamiento de la sociedad, así como para procurar el acceso a diferentes cargos civiles y eclesiásticos. Los reclamos de los sectores indígenas, mestizos y criollos que surgían en estos espacios, se identificaban con el lugar subalterno que les confería el poder colonial y en tal sentido, los políticas jesuitas mostraron una integración estamental, ya que desde muy temprano extendieron su influencia a los diversos estratos sociales (González, 2014a). Esto suscitó entusiasmo pero también una oposición violenta tanto por el poder 
que fueron acumulando como por sus métodos pedagógicos (Glave, 2013), que abrían la puerta a discusiones que cuestionaban el sistema colonial y por lo tanto atentaban contra el orden establecido. Sin embargo, existía una buena justificación para educar a los líderes étnicos, ya que en materia de religión, se suponía que siendo propiamente doctrinados se convertirían en los mejores portavoces del cristianismo. ¿Cómo impactaría esta situación en la educación religiosa de una sociedad como la andina, donde la religión era la base de la organización civil y social?

Dentro de la educación, la evangelización llevada a cabo por los jesuitas ocupó un lugar destacado, caracterizándose por el contacto profundo con las diferentes regiones y las costumbres de cada población, para las que fue necesario adoptar y modificar la experiencia religiosa europea. La concepción probabilista que implicaba el traslado de juicios morales desde el terreno teórico (apoyado en causas y leyes) al terreno de la opinión (apoyado por motivos y circunstancias puntuales), convertía gran parte de los asuntos morales, jurídicos y políticos en problemas pragmáticos y de comunicación intersubjetiva, lo que resultaba muy apropiado para llevar adelante el contacto con las comunidades americanas (Ballón, 2008). Desde fines del siglo XVI, como lo muestra el jesuita José de Acosta en De procuranda indorum salute (1589), se desarrollaron estrategias comunicativas que apuntaban a considerar las características de la cultura y religión autóctona. Este espíritu de trabajo estuvo presente desde las primeras recomendaciones del General Francisco de Borja al padre Ruiz de Portillo (1567) donde el modelo de instrucción acomodó las ideas de la nueva fe, tolerante a las costumbres de neófitos, como los apóstoles que convivieron con las tradiciones paganas al inicio del cristianismo. Para ello, fue necesario un esquema de conducta muy flexible y un cierto tipo de "relativismo histórico" según Martel, que expresara la múltiple experiencia geográfica y social, y al mismo tiempo sirviera de justificación e instrumento de trabajo ante la emergencia de casos inusitados "(...) ya no se trata de aplicar la tabla de valores universales a casos particulares, sino a la inversa, de adecuar a los casos particulares la tabla universal” (Martel 2012, p. 21).

Recuperando las ideas de Pablo Macera (1969), Martel recuerda que el Probabilismo implicaba una toma de conciencia de la historicidad y temporalidad de la religión, es decir, un reconocimiento de sus dimensiones terrestres. La Iglesia y la religión, más allá de las coyunturas puntuales, conformaban una unidad atemporal. Desde la concepción probabilista, el único aspecto inmutable del cristianismo era el divino, pero el sacrificio de Cristo, la revelación, las historias de los apóstoles, entre otras, eran vistos desde una perspectiva histórica, por lo que las prácticas religiosas debían considerar las variantes en la liturgia y en la interpretación del dogma (Martel 2012, p. 21). Así lo señalan las reglas de la Ratio Studiorum- Razón de ser de los estudios de la Compañía de Jesús- (publicada en 1599 y reeditada en la VII Congregación romana en 1616):

Y como puede haber variedad según las regiones, los tiempos y las personas, en lo tocante al orden y las horas dedicadas al estudio, en las repeticiones, discusiones y otros ejercicios (...) lo que considerare en su provincia más conveniente al provecho mayor de las letras, indíquelo al Prepósito General; para que finalmente se decidan los detalles para todo lo necesario, pero de manera que se acerque lo más posible al orden común de estudios de los nuestros" (Ratio Studiorum Oficial [1599] 1616, p. 33). 
Según Pablo Macera, el hecho de que las campañas misioneras de la compañía se extendieron más que otras órdenes, les posibilitó conocer los cambios culturales que producía la evangelización de las comunidades del nuevo mundo y tener nuevas percepciones y una conducta más flexible. Por otro lado y a diferencia de otras órdenes, los jesuitas no contaban con tradiciones institucionales anteriores al siglo XVI, por lo que su aceptación del probabilismo era consecuente con su forma de pensar, ya que expresaba un deseo de apartarse de las severidades primitivas del cristianismo y lograr la reconciliación entre lo sagrado y las exigencias del mundo real (Bacigalupo, 1999; Martel, 2012).

De claro espíritu probabilista, la Ratio Studiorum, estaba inspirada en las concepciones ignacianas y las experiencias de los primeros colegios educativos y puede considerarse la directriz, ya que influyó en la organización de sus escuelas y guió por doscientos años el estilo educativo de los jesuitas. Las primeras constituciones recomendaban un método pedagógico análogo a la hoy llamada psicología del alumno, adaptándose en base al carácter, que por lo general definían al indígena como tímido y retraído, reconociendo además el peligro que conllevaba tratarlos mal e imponerles miedo, ya que existía el riesgo de que acumulasen odio secreto, lo que los volvería peligrosos a futuro (Alaperrine Bouyer, 2007). En este sentido, Ignacio de Loyola (14911556) había dedicado los últimos años de su vida a escribir las Constituciones de la nueva Orden Religiosa, [1491- 1556] destacando para las concepciones educativas la IV Parte $^{6}$, donde se manifiesta la intención de conciliar los fines idealistas con los medios concretos para llevarlos a la práctica: "Y porque en los particulares ha de haber mucha variedad según las circunstancias de lugares y personas, no se descenderá aquí más que a lo particular, con decir que haya Reglas que desciendan a todo lo necesario en cada colegio" (Constituciones, IV P, p. 207). Las situaciones insólitas, requerían metodologías que permitan discutir las leyes para atender a las subjetividades, sin dejar de ser fiel a la Iglesia Católica. Estas consideraciones impulsaron una política educativa para la doctrina, que tuvo su impacto en el Tercer Concilio Limense (1582-83) y aunque tuvo algunas variantes en los dos siglos posteriores, guió la instrucción religiosa hasta el momento de la Expulsión de la Orden.

Haciendo referencia al probabilismo de Diego de Avendaño, Ballón destaca la importancia y vigencia a través de los años y hasta el momento de la expulsión, que tuvo dicha corriente en el Perú, hecho corroborado en el relevamiento de archivos del siglo XVIII, llevado a cabo por Manuel Burga Díaz en 1969 para su tesis Nueve bibliotecas jesuitas en el momento de su expulsión. Se trata de nueve inventarios de diferentes bibliotecas jesuitas peruanas, que fueron confeccionados en el momento de la expulsión de la orden del virreinato, lo que lo hace más interesante. Entre los nueve colegios jesuitas, aparece el Noviciado de Lima, Arequipa, Trujillo, Ica, Huamanga, Huancavelica, Potosí, La Paz y Cochabamba. El registro pone de relieve la existencia de 82 ejemplares de las obras de Avendaño, colocándolo entre los 38 autores más frecuentes de dichas bibliotecas (entre Platón, Aristóteles, Santo Tomás, San Agustín y Suárez). A su vez, de estos autores mencionados, el historiador citado por Ballón registra un mínimo de siete autores probabilistas (Diana, Sánchez, Escobar, Vásquez, Castro Palao, Caramuel y

\footnotetext{
${ }^{6}$ La obra, dividida en diez Partes, es un manual de formación para la vida de la Compañía, de la cual la IV parte es la mejor fuente para conocer el pensamiento de Ignacio sobre el apostolado de la educación. A su vez, Ignacio la revisó parcialmente a raíz de las nuevas experiencias (Constituciones Parte IV, [14911556])
}

74 Carla Maranguello. ¿Difusión de ideas subversivas?. La condena de los Borbones... 66-85. 
Avendaño), además de Suárez ya mencionado. Ballón reflexiona sobre la importancia del monopolio que implicaba la enseñanza jesuita para diversos sectores de la sociedad andina, por lo que tal registro es una prueba de la influencia de Avendaño y del probabilismo en el virreinato peruano de los siglos XVII y XVIII (Ballón, 2008).

Por otra parte quedaría claro que el espíritu probabilista estaba presente en la concepción jesuita de la enseñanza, y más allá de las variables que podían presentarse en cada institución, en relación a la lectura puntual de autores probabilistas por parte de los profesores (y en algunos casos de los alumnos), era el método que subyacía en el modo de impartir enseñanza. Así lo confirman las Reglas comunes a todos los profesores... de la Ratio, donde se hacía clara referencia al probabilismo y a la licitud de las opiniones de acuerdo a las circunstancias: “(...) Indíquese la opinión más probable. De tal manera apoye sus opiniones, que si alguna otra fuere probable y esté apoyada por buenos autores, indique que también ella es probable" (Ratio Studiorum Oficial, 1616, p. 65).

Tanto los colegios más importantes que estuvieron bajo la administración de los jesuitas, en las ciudades como en las misiones, señalan cierta evolución de los contenidos con el paso del tiempo, pero dentro de las concepciones ignacianas de enseñanza (Alaperrine Bouyer, 2007). Si bien las reflexiones sobre cómo y para qué educar no tenían un foco coordinador, la conciencia de la importancia de esos espacios para el manejo de la sociedad a futuro, la naturaleza y licitud del dominio colonial, la servidumbre de los nativos, el poder de los representantes del rey, la fe y religión, es decir, cuestiones relativas al pensamiento filosófico, teológico, jurídico y político, tenían un claro sesgo probabilista. Por ello, cuando los jesuitas asumieron el pedido de abrir los colegios, lo hicieron con "una filosofía muy precisa sobre el destino de la sociedad nativa dentro del conjunto colonial" (Glave, 2013, p. 8).

En el año 1725, bajo el gobierno del Virrey Castelfuerte, la educación escolástica impartida por los jesuitas llegó a su cumbre con la creación en la Universidad de San Marcos de una cátedra dedicada a Francisco Suárez, cuya doctrina fue colocada casi al mismo nivel que la de Santo Tomás (Peralta Ruiz, 1996). La influencia intelectual de la compañía, las implicancias escépticas y liberales del probabilismo, se hallaban en un momento de apogeo, tanto en las grandes ciudades como en los pueblos de indios, aunque en pocos años la situación se revertiría.

\section{Los jesuitas y las imágenes}

En el marco del adoctrinamiento de los indígenas en América, la admisión de cierta ambigüedad en la práctica cristiana y la continuidad de las tradiciones rituales locales, impactó en la imagen. El barroco buscó una relación íntima y personal entre la imagen y el fiel creyente para sumergirlo en una realidad más tangible, abriendo una vía de libertad estético visual, acorde al recurso retórico y pedagógico de ideología contrarreformista (Gisbert, 1980). Por otro lado, los jesuitas consideraron especialmente las posibilidades de la imagen para reemplazar las palabras y despertar los sentidos. La aplicación de los sentidos señalada en la Ratio- y también en los Ejercicios Espirituales de San Ignacio- delinean una manera de guiar a través de experiencias que apelen a todos los sentidos, para lograr la producción de imágenes mentales a partir del texto. No obstante, los inconvenientes en la transmisión de la doctrina, se presentaron evidentes 
en las formas artísticas, siendo que las políticas flexibles que buscaban facilitar la transmisión y comprensión del cristianismo a través de la incorporación de elementos de la religiosidad andina, daban lugar a idolatrías. Así por ejemplo, la asimilación de la Virgen, Jesús y Santos con cerros y huacas, hacía volver a los nativos a sus antiguas prácticas religiosas, siendo esto más perceptible en la pintura y escultura, como demostró el contexto de extirpación. ${ }^{7}$

La importancia de la imagen para la instrucción religiosa, fue un tema central del Concilio de Trento (1545-1563), que tuvo su impacto fundamentalmente en el III Concilio Limense (1582-83), y que estableció pautas que estuvieron vigentes durante todo el siglo XVIII. El peligro del culto hacia los ídolos mediante la utilización de imágenes, respondía según lo establecido en el concilio romano, a una forma desordenada de veneración que nada tenía que ver con la utilización que alentaba la iglesia. No obstante, para sortear este obstáculo se acudió a la ayuda de la palabra a través del sermón, que cargaba con un sentido visual, ya que se acudía constantemente a las analogías con objetos del mundo reconocible por los conversos. El jesuita Pablo José de Arriaga, uno de los principales extirpadores de idolatrías, recordaba a sus pares la importancia de este tipo de técnicas para que los conversos asuman afectivamente el dogma, incluyendo muchas veces elementos básicos de la religiosidad andina, como en este caso el maíz:

[...] Los sermones han de ser proporcionados a su capacidad (...) convenciéndoles con más razones naturales, que ellos entiendan, [...] Como yo vi, que lo hacía excelentemente uno de los Visitadores [...] sacaba en el catecismo una mazorca de maíz, y preguntándole de cuántos granos había nacido aquella mazorca, y respondiendo que de uno. ¿Pues cómo siendo este blanco, o negro, o colorado, (...) salen en esta mazorca unos granos blancos, otros negros, otros pardos? [...] A este modo han de ser los sermones (Arriaga, 1922 [1621], p.117)

En las iglesias de los pueblos de indios, la doctrina era acompañada por las imágenes, que constituían una guía dentro del circuito religioso. Las fachadas de las iglesias tuvieron un papel destacado como elemento de conexión entre el espacio interno y externo. En este sentido, destaca la doctrina de Juli en la provincia de Chucuito, ubicada en el Dpto. de Puno en Perú, que presenta un conjunto de iglesias reduccionales que fueron organizadas por el virrey Francisco de Toledo desde 1573, quien expulsó un año antes a los dominicos que se habían encargado de la primera evangelización en la zona y los reemplazó por integrantes del clero secular. Los jesuitas, que tomaron la doctrina en 1576, iniciaron un proceso que fue prolongado hasta el siglo XVIII.

Desde sus primeros años de trabajo, habían organizado sus escuelas donde se proporcionaba una sólida base de doctrina cristiana, alineada a las directivas de José de Acosta. Estas escuelas eran gratuitas y estaban al cuidado de hermanos estudiantes o coadjutores, y aunque iban orientadas especialmente a los indios nobles o hijos de caciques, eran para todos los grupos sociales y la asistencia era muy numerosa. La enseñanza comprendía el catecismo, la aritmética, el lenguaje y también se enseñaba la música, que era fundamental en la liturgia (Meiklejohn, 1988). ${ }^{8}$ Por otro lado, Vargas Ugarte (1941) ha señalado que existía una escuela -y una iglesia- por cada parcialidad, ya que

\footnotetext{
${ }^{7}$ Teresa Gisbert (1980) ofrece muchos ejemplos al respecto.

${ }^{8}$ Norman Meiklejohn (1988, p. 239) utiliza varios testimonios de la documentación del ARSI, Historia General del Perú, II, (Vol. 24).
}

76 Carla Maranguello. ¿Difusión de ideas subversivas?. La condena de los Borbones... 66-85. 
otra característica de Juli era la adaptación al esquema espacial prehispánico y el pueblo se dividía en cuatro parcialidades. Así a San pedro le correspondian los Huancollos, a Santa Cruz los Incas, Chambillas y Chinchallas, a la Asunción los Mojos o Mochos y a San Juan los Ayancas. Finalmente, se contaba con seminarios para quienes decidían formarse como misioneros y una escuela de lenguas, para que los candidatos a la Compañía pudieran dirigir sermones a la comunidad (Gutiérrez, 1978).

Los jesuitas acompañaron el proceso de desarrollo de los programas iconográficos de la ornamentación arquitectónica eclesiástica, que desde fines del siglo XVII y durante el siglo XVIII, estuvo a cargo de grupos nativos, como ha demostrado Ramón Gutiérrez (1978) a través de documentación del Archivo de Prelatura de Juli. Dicha ornamentación se extiende en las portadas de acceso a diferentes espacios de culto y jugó un rol sustancial para la orientación del circuito religioso y como elemento de transición entre los diferentes espacios. Destacan en las portadas gran cantidad de aves pertenecientes al entorno, variedades de flores y plantas de empleo ritual y alimenticio, valvas marinas, animales relevantes en la iconografía andina como felinos, monos y vicuñas. Esta iconografía se superpone a diferentes elementos de la simbología cristiana, como monogramas de María y de Cristo, símbolos de las órdenes religiosas, elementos de la Pasión y diferentes tipos de ángeles. La presentación de elementos naturales que reemplazan muchos motivos usados para ornamentar las portadas europeas, por plantas y animales del altiplano y de otros pisos ecológicos, resulta significativa ya que para el hombre andino la naturaleza tenía en sí misma contenidos religiosos, aspecto que se revela en la mayor parte de la iconografía de las producciones artísticas que van desde antes de la cultura Chavín hasta la conformación del Tawantinsuyu. Además del extendido uso de los elementos naturales para fines religiosos y medicinales, en el hostil ambiente del altiplano, tanto la producción agraria como los beneficios del clima debieron garantizarse para asegurar la existencia misma de la comunidad, por lo que la percepción del medio ambiente se expresaba como una relación que ligaba el orden social con el orden cósmico. ${ }^{9}$

El origen de este estilo se ubica en la fachada de la Compañía de Arequipa (1698-99), impulsado por la orden jesuita, el cual se extendió rápidamente hacia el Sur, teniendo impacto especialmente en la provincia de Chucuito mediante la influencia de la iglesia de Santa Cruz de Juli, según documentación citada por Alexander Gauvin Bailey, apareciendo en las iglesias de San Pedro de Zepita (c.1735), Santiago de Pomata (c.1754-1794), San Carlos de Puno (c. 1787), para expandirse finalmente a varias ciudades del Alto Perú, como La Paz y Potosí (Bailey 2010; González 2014b). Los casos más interesantes aparecen en la doctrina de Juli, en especial en las iglesias de la Santa Cruz (c.1712 y 1753) (Fig. 1) y San Juan (concluida antes del año 1767) (Fig. 2).

\footnotetext{
${ }^{9}$ La presencia de elementos naturales vinculados con la religiosidad andina en las fachadas de los conjuntos reduccionales de Chucuito, ha sido trabajado por mi previamente con la utilización de bibliografía y estudios de casos sobre producciones artísticas prehispánicas, además de la colaboración de especialistas en etnobotánica del área sur andina. Véase Maranguello Carla, 2015 "Religiosidad andina y fuentes doctrinales. Consideraciones sobre el contexto evangelizador de desarrollo de la iconografía ornamental en Chucuito colonial”. Revista Temas Americanistas [en línea] ISSN 1988-7868, №35, 2015, pp. 37-59.
} 


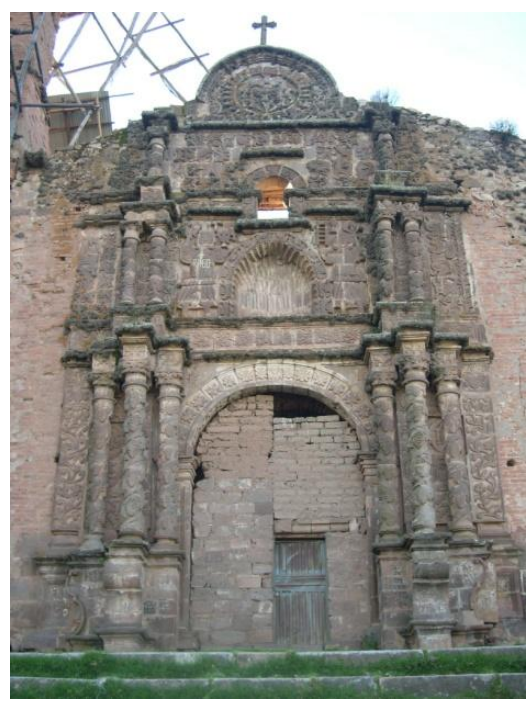

Fig. 1. Iglesia de Santa Cruz de Juli. (c.1712 y 1753). Dpto. Puno- Perú. Fot.: trabajo de campo UBCYT F-343.

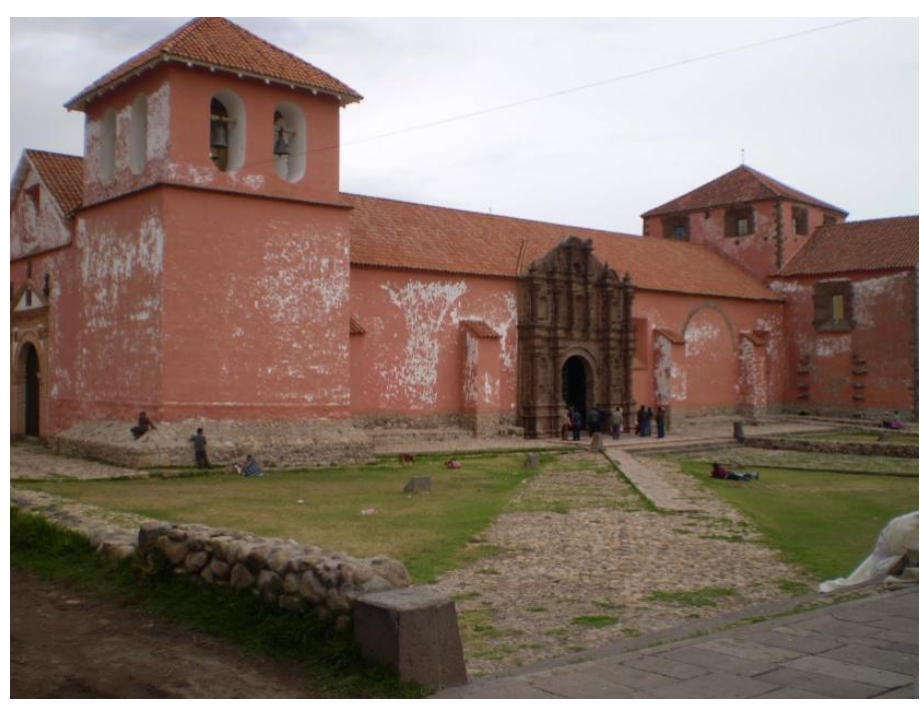

Fig. 2 Iglesia de Santa Juan de Juli, (concluida antes de 1767). Dpto. Puno- Perú. Fot.: trabajo de campo UBCYT F-343.

En la portada del Bautisterio de la iglesia de Santa Cruz (Fig. 3) aparecen flores de chamico o datura del género Brugmansia, presentes en el arte lítico desde culturas del Horizonte Temprano como Chavín de Huantar (sierra de Ancash- c. 900-200 a.C.), particularmente en el Obelisco Tello, en íntimo vínculo con el sistema religioso y que debió corresponder según Mulvany de Peñaloza (1984) a la capacidad de dicho vegetal de producir algún efecto alucinógeno en sus propiedades. En las columnas principales, monos comen frutas de las tierras calientes como zarzaparrillas y cacaos (Fig. 4), similares a los monos con ulluchu que aparecen en cerámicas moche (costa norte de Perú- c. 100-800 d.C.). Rematan el acceso a la portada en la dovela del arco, tres valvas dispuestas de manera simétrica junto con representaciones de panochas de maíz, y constituyen el eje central de la composición, alineados con el símbolo de la orden de la Compañía de Jesús. Si bien las valvas aparecen en la iconografía cristiana como atributo de Santiago el Mayor, en el mundo andino se consideraban especialmente por la importancia que tenían como ofrendas acuáticas, apareciendo ya desde Chavín las conchas Spondylus y los Strombus vinculados a rituales de fertilidad, utilizados como ofrendas para atraer a las fuerzas naturales a una relación recíproca con la sociedad (Burger 1983). Por su parte el maíz, era la principal ofrenda en sacrificios y al igual que las hierbas de uso alucinógeno, sus sustancias embriagantes se corresponden con la asignación de valor de médium a través de estados alterados de conciencia. De la misma manera, la portada lateral de acceso a la iglesia de San Juan (Fig. 5) presenta en las dovelas del arco principal, diversas flores compuestas, similares a las flores de cactus, especialmente Achuma (Echinopsis Pachanoi), flores de tabaco, (Nicotiana rústica), tipos de flor de la pasión (passiflora caerulea) en todos los casos de arraigado uso medicinal y alucinógeno en el mundo andino (Rainer y Douglas, 2015). Estas flores flanquean el escudo de la orden. En las columnas del piso inferior, aparecen felinos que se alternan con zarzaparrillas y aves (Fig. 6). En los pisos superiores, las columnas incluyen flores campaniformes al modo del chamico o datura, como en la Santa Cruz. Rematan el conjunto valvas que envuelven un cordero, en referencia al Santo a quien se dedica la iglesia. 


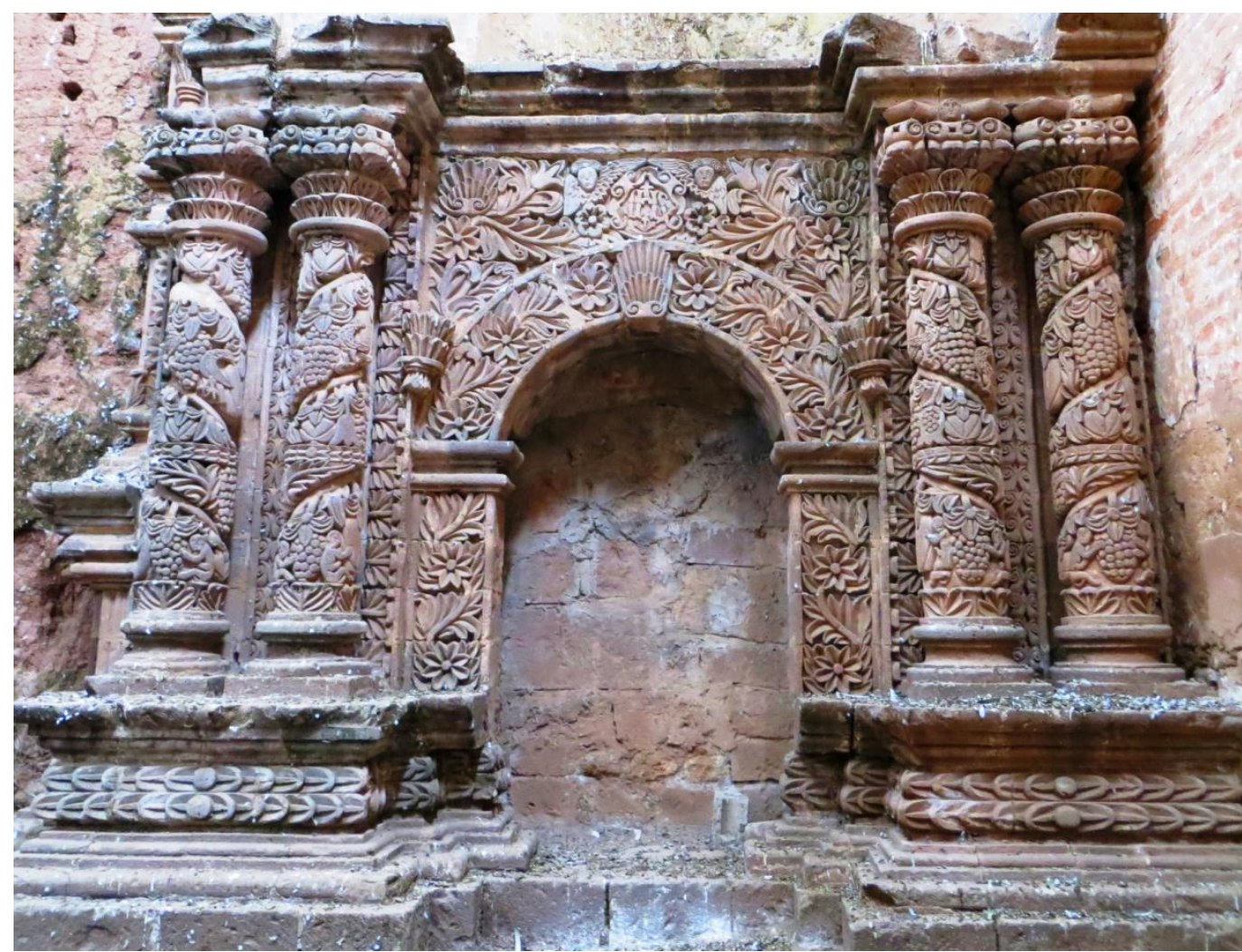

Fig. 3 Portada del bautisterio de la iglesia de Santa Cruz de Juli. (c.1712 y 1753). Dpto. PunoPerú. Fot.: Carla Maranguello (trabajo de campo UBCYT F-343)

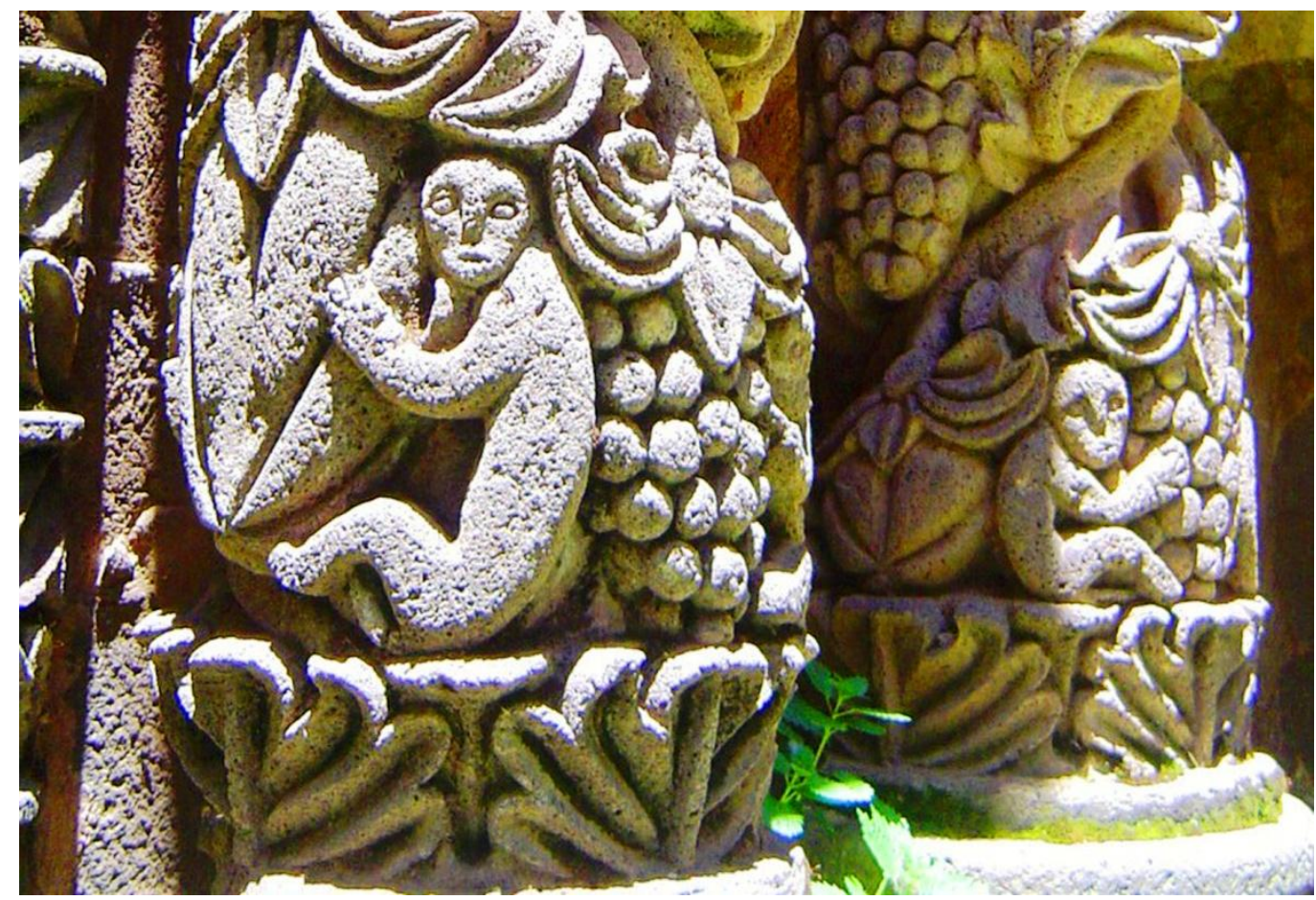

Fig. 4 Bautisterio de la iglesia de Santa Cruz de Juli. (c.1712 y 1753). Dpto. Puno- Perú. Detalle de monos con cacaos y zarzaparrillas en las columnas. Fot.: Carla Maranguello (trabajo de campo UBCYT F-343) 


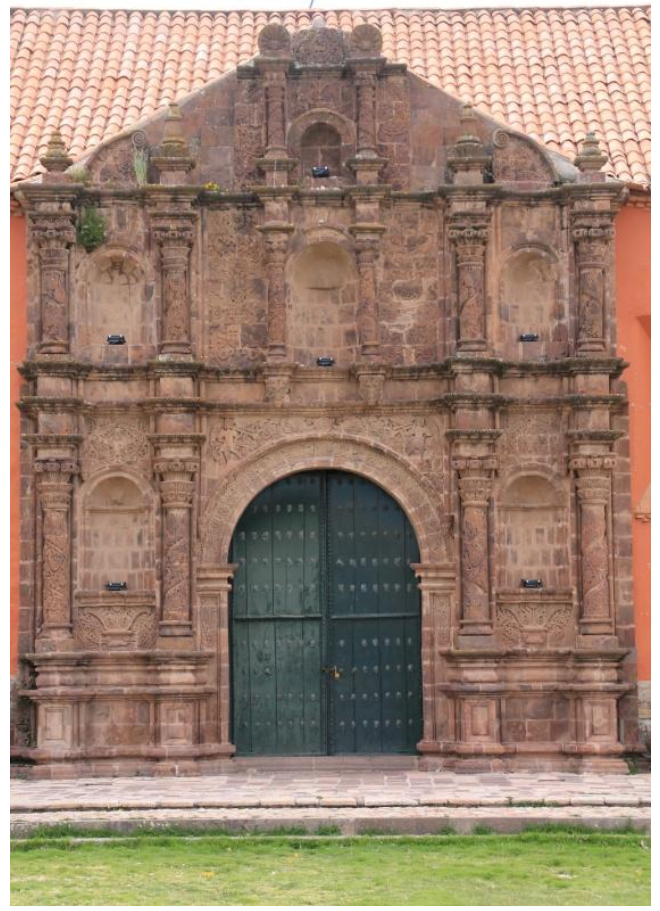

Fig. 5 Iglesia de Santa Juan de Juli, (concluida antes de 1767). Dpto. Puno- Perú. Portada lateral. Fot.: R. González (2016).

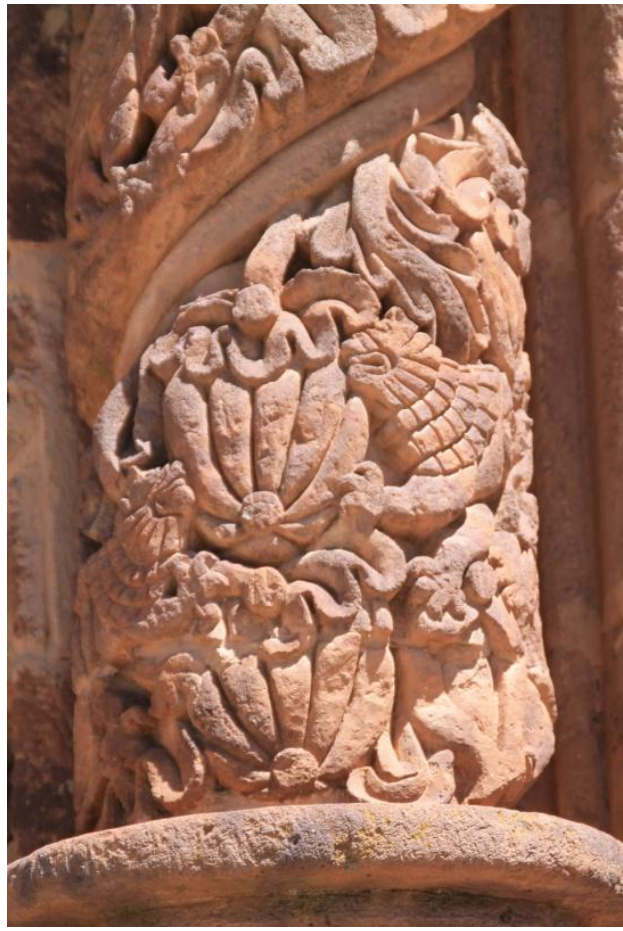

Fig. 6 Iglesia Juli, Detalle de las columnas del piso inferior de la portada lateral con felinos y frutas. Fot.: trabajo de campo UBCYT F-343.

En este punto podemos preguntarnos, ¿Porque se admitían estos elementos? ¿Podían estas imágenes ser realizadas a expensas de los jesuitas o se trató de un acuerdo tácito? Trasladada a las imágenes, la concepción probabilista era consecuente con la aceptación e inclusión de elementos de la religiosidad andina. Sumado a la preocupación de los doctrineros por la evangelización deficiente, cierta flexibilidad en relación con la búsqueda de lugares comunes entre ambas religiones, determinó la supervivencia de motivos de raigambre prehispánica adaptados al nuevo contexto. A diferencia de los problemas que podían tener estas políticas flexibles con la pintura y la escultura (como se vio en el contexto de extirpación), en el caso de la ornamentación, su apariencia meramente decorativa, la volvía más hermética al control institucional.

Juan Carlos Estenssoro (2003) señala la tradición greco latina de los grutescos, asociada a representaciones de los demonios a los que rendían culto los paganos, a lo que se sumó en Perú la constante de incluir a sus dioses metamorfoseados en seres híbridos en columnas o altares, - a lo que podemos sumar fachadas y pinturas muralespor lo que sería evidente para el autor que los grutescos tenían importancia en la comunicación visual colonial, en especial la que le otorgaron los indígenas. Si bien al principio el Tercer Concilio Limense los consideró inofensivos, a medida que avanzaba el tiempo, la iglesia comenzó a controlarlos, por lo que tendieron a desaparecer de los contextos sagrados o a transformarse en motivos vegetales no antropomórficos. Tomando al jesuita Ludovico Bertonio (1612), Estenssoro refiere que los jesuitas de Juli, al momento de crear un vocabulario para su traducción a las lenguas indígenas, retomaron las relaciones entre imagen y escritura, asimilando a ésta a la figuración de grutescos. Estos seres que se enlazan y se superponen en el dibujo a partir de fragmentos de especies animales y vegetales diversas, como las palabras se siguen unas a otras, serían designa- 
dos por la misma expresión que el renglón de un texto. Además de la importancia de la relación entre la escritura y la imagen, es claro que los grutescos por su composición con figuras híbridas, invitaban a articular formas y temas de diversas tradiciones, facilitando así la integración de motivos locales (Estenssoro, 2003).

Por otro lado, utilizando documentación del Archivo General Nacional del Perú (AGNP), más precisamente las Temporalidades (1767), ${ }^{10}$ Ricardo González ha señalado que en las bibliotecas de Juli había ejemplares del Rationale Divinorum Officiorum de Guillermo Durango (1296), donde se hace hincapié en la simbología de los elementos arquitectónicos del templo. Allí Durango destaca que mientras las pinturas y esculturas presentaban personajes o exponían historias a modo narrativo, la ornamentación apelaba a otro tipo de comunicación donde los objetos participantes no eran textualizables, buscando la generación de climas que apelen al impacto afectivo. De esta forma, se creaba una comunicación que pasaba por la percepción de formas sugestivas, pero carentes de relato a la vista, dando lugar a la inclusión de formas ambiguas. El tipo de mensaje no narrativo con que operaba la ornamentación, eludía problemas conceptuales y lingüísticos y permitía incluir elementos andinos recontextualizados, dejando "a salvo la ortodoxia, que era el límite de la flexibilidad jesuita” (González, 2014b, p. 277).

En este punto, y siendo que la ornamentación arquitectónica más elaborada pertenece a los años previos a la expulsión, podemos al menos dudar de que los jesuitas hayan ignorado la posible presencia de elementos naturales utilizados con fines rituales o significativos desde el punto de vista religioso y, por lo tanto relativos al orden socio cultural andino.

\section{Consideraciones finales. La condena al probabilismo y la expulsión de los jesuitas.}

La Compañía de Jesús había adquirido gran presencia en el virreinato peruano, y a lo largo del siglo XVIII se había convertido en la orden religiosa más poderosa. En el marco de la secularización del clero que caracterizó la política regalista de los Borbones, se trató de apartar a los indios de los moldes que habían utilizado las órdenes mendicantes, que habían dado un margen de flexibilidad en la incorporación al catolicismo. Se cuestionó la participación jesuita en el ámbito académico e intelectual y se buscó controlar los espacios educativos que fueron señalados como posibles focos de conspiración (O’Phelan, 1995).

En el año 1769, Carlos III convocó a concilios eclesiásticos en todos los reinos de Indias mediante el llamado Tomo Regio, con el objetivo de erradicar las doctrinas que se consideraban relajadas, y culpables de alentar el regicidio, entre las que el probabilismo y los jesuitas como sus principales promotores, fueron el blanco principal. Por una cédula del 12 de agosto de 1769 se prohibió explícitamente la enseñanza de ascendencia jesuítica, mencionando incluso a sus maestros, entre los que destacaba Francisco Suárez, cuyas cátedras fueron suprimidas (Rosas Lauro 2009). En 1772, luego de la expulsión de los jesuitas y respondiendo al Tomo Regio, se llevó a cabo la celebración del VI Concilio Limense, con la gestión del Virrey Amat, con el propósito de reforzar la idea de desterrar la influencia intelectual jesuita.

\footnotetext{
${ }^{10}$ Testimonio de los autos actuados sobre el extrañamiento de los jesuitas que estaban en la residencia de Juli.
}

81 Carla Maranguello. ¿Difusión de ideas subversivas?. La condena de los Borbones... 66-85. 
Si en otros tiempos ha sido necesaria su convocación, en ninguno más propiamente que en los presentes (...) para exterminar las doctrinas relajadas y nuevas, sustituyendo las antiguas y sanas, conformes a las fuentes puras de la religión y restableciendo también la exactitud de la disciplina eclesiástica (...) Real Cédula Agosto 1769 (Vargas Ugarte, 1951, p. 207)

En el marco del Concilio, se llevaron a cabo enfrentamientos que estaban dirigidos a condenar el probabilismo, lo que no fue ratificado ni por la corona ni por el papado, aunque se lograron prerrogativas de concilios provinciales, rigurosidad para el ordenamiento de sacerdotes y disposiciones sobre las fiestas religiosas para impedir que se filtren elementos populares, entre otras medidas. Las opiniones en el concilio estuvieron divididas. Las discusiones principales se dieron entre Miguel Durán y Ángel Espiñeira, quienes establecieron una crítica al probabilismo jesuita, contra el franciscano Juan de Marimón quien, siendo nombrado como asesor del Virrey Amat, defendió al probabilismo, lo que le costó censura y castigo. Hubo otros personajes como Agustín Gorrichátegui, obispo de Cuzco y Manuel Del Alday, obispo de Santiago de Chile, que estuvieron del lado de Marimón. En torno al debate, se generaron algunos textos publicados el mismo año del concilio, entre ellos, Idea Sucinta del Probabilismo de Juan Lope de Rodó, quien tomó una postura opuesta al probabilismo, y La Antorcha Luminosa de autor anónimo, que constituía una defensa al probabilismo más allá del plano religioso, desde una crítica racionalista y una conciencia de condicionamientos sociales, con argumentos que demuestran que los debates siguieron vigentes una vez expulsados los jesuitas (Rosas Lauro, 2009).

Bacigalupo se pregunta ¿Cómo pudo convertirse el probabilismo, una simple actividad intelectual, en una amenaza política para el régimen colonial? Se responde aduciendo que fue una ideología que, desarrollada en una circunstancia histórica concreta, constituyó una oposición firme al despotismo borbónico. Los cuestionamientos posibilitados por el probabilismo, además de inmiscuirse en el plano político, tuvieron su impacto en la enseñanza doctrinal, cuya flexibilidad dejó penetrar elementos de la religiosidad andina, que constituían la base del orden social y político andino. Señala Glave en relación a los colegios de caciques: "Con base en los discursos teológicos y filosóficos de la época, tanto líderes indios como los pensadores eclesiásticos y civiles, sensibles a la tiranía, denunciaron que las leyes que se daban para protegerlos eran usadas con perversidad por quienes debían implementarlas" (Glave, 2013, p. 4). En este sentido el colegio de los jesuitas en Cuzco - así como otros espacios educativos- tendieron a diversificar la composición social del alumnado, por lo que se habían convertido en espacio de confluencia de caciques y criollos, donde podían convivir y dialogar. Incluso en el colegio de San Borja, se había adoctrinado a un segmento de la clase dirigente que en 1780 se revelaría contra la corona. ${ }^{11}$ (O’Phelan, 1995).

Es evidente que la situación se hizo extensiva a los pueblos de indios, donde además de la influencia de los caciques, los métodos de enseñanza jesuítica jugaron un papel destacado a nivel ideológico y posibilitaron cierta libertad del pensamiento. Según Vargas Ugarte, en el momento que se publicó el decreto en que se hacía referencia a la expulsión en 1767, se produjo un estallido que casi genera un motín. El marqués de Aro

\footnotetext{
${ }^{11}$ Según declaración del escribano E. Escarcena, de la Legislación de la Audiencia de Cuzco que recoge O’Phelan (1995, p. 32), Tupac Amaru había expresado su deseo de legislar el Cuzco desde el colegio de la Compañía.
} 
así lo describe en una carta al virrey Amat, donde le transmitió el nivel de excitación que produjo esta medida, y de la necesidad que hubo de acudir a los mismos Padres para calmar a la población (Vargas Ugarte, 1941). La conmoción no se limitó a Juli, sino que se extendió al resto del virreinato.

(v) Un decreto real mandaba que "los padres salgan fuera deste colegio (...) con el sigilo que se requiere sea |se ha| experimentado especial moción y patrullas formadas de indias que mezcladas con indios se andan por el rededor del Colegio y calles con clamores y alaridos y siendo estos de ordinario los principios de las sublevaciones entre los desta naturaleza (...) se reduzcan a él sin estrépito ni movimiento alguno a las tres de la mañana para estar al reparo de cualquier invasiones (sic)

(...) A las 3.30 de la mañana del día 4 salieron los padres por la puerta falsa del colegio "para evitar cualquier tumulto por la muchedumbre (26) de indios que con su clamor extraordinario estaban sin quererse apartar de la puerta principal y Plaza [3.9.1767, Temporalidades- Juli]. ${ }^{12}$

Finalmente la polémica terminó con una Real Cédula de 1778, que prohibía toda discusión vinculada con la expulsión de la Compañía de Jesús.

\section{Referencias}

Alaperrine Bouyer, M. (2007). La educación de las elites indígenas en el Perú Colonial. Lima: Instituto de Estudios Peruanos, Instituto Riva-Agüero.

Arriaga, P. J. de 1922 [1621], La extirpación de la idolatría en el Perú. Dirigido al Rey N. S. en su Real Consejo. Lima: Imp. San Martín y Cía.

Avendaño, D. de [1688] 2009. Thesaurus Indicus, España: Ediciones de la Universidad de Navarra, Introducción y traducción de Ángel Muñoz García Vol.I

Bacigalupo, L. (1999). Probabilismo y Modernidad. Un capítulo de la filosofía moral del siglo XVIII y su repercusión en Perú. En: Armas Asín, F. (comp.). La construcción de la Iglesia en los Andes (siglos XVI-XX) (pp. 257-300). Lima: Pontificia Universidad Católica del Perú.

Ballón, J. C. (2004). Diego de Avendaño (1549-1688) y los orígenes coloniales de la filosofía en el Perú. Patio de letras, Año II, vol. II, Nº1, pp. 97-107

(2008). Diego de Avendaño y el probabilismo peruano del siglo XVII. Revista de Filosofía, $\mathrm{N}^{\mathrm{o}} 60,-3$, pp. 27 - 43

Burger, R., (1993). El centro sagrado de Chavín de Huantar. En: Townsend, R. F. (ed.) La Antigua América. El arte de los parajes sagrados (pp. 265-277). México: The Art Institute of Chicago.

Bussmann, R. y Douglas S. (2015). Plantas medicinales de los Andes y la Amazonía. La flora mágica y medicinal del Norte de Perú. Trujillo, Perú: Centro William Brown, Jardín Botánico de Missouri. Graficart.

${ }^{12}$ AGNP, Temporalidades, 130 - 2. Cortesía de Dr. Ricardo González (FFyL-UBA). 
Concilios Limenses: 1551-1772. (1951). Lima: Universidad Católica del Perú.

Constituciones de la Compañía de Jesús (1491- 1556). Recuperado de: www.documentacatholicaomnia.eu

Estensoro Fuchs, J. C. (2003). Del paganismo a la santidad. La incorporación de los indios del Perú al catolicismo (1532-1750) (trad. Del francés por Gabriela Ramos). Lima: IFEA.

Gisbert, T. (2008). Iconografía y mitos indígenas en el arte. La Paz: Gisbert y Cía.

Glave, L. M. (2013). Entre la sumisión y la libertad, siglos XVII-XVIII, Vol.2, Colección Pensamiento Educativo Peruano. Perú: Fondo editorial de la Derrama Magisterial.

González, R. (2014a). El estilo mestizo y la disyuntiva integracionista en el Perú Colonial. XI Jornadas Estudios e Investigaciones. Las artes como espacio experimental y profético de los diálogos entre las culturas y las ideologías: la gran tarea del tercer milenio. Bs. As.: Instituto "Julio E Payró".

(2014b). La Compañía de Jesús y la renovación de la iconografía ornamental en el sur andino. VII Encuentro internacional sobre Barroco, "Migraciones y rutas del Barroco” La Paz: Fundación Visión Cultural y Fundación Altiplano.

Gutiérrez, R. (1978). Arquitectura del altiplano peruano. Buenos Aires: Libros de Hispanoamérica.

Martel Paredes, V. H. (2005). La filosofía Moral: el debate sobre el probabilismo en el Perú (SXVII-XVIII). Lima: Universidad Nacional Mayor de San Marcos. Tesis.

Meiklejhon, N. (1988). La iglesia y los lupaqa de Chucuito durante la colonia. Lima: Instituto de Estudios Aimaras.

Mulvany de Peñaloza, E. (1984). Motivos fitomorfos de alucinógenos en Chavín. Chungará 12: 57-80. Chile: Universidad de Tarapacá.

O'Phelan, S. (1995). La gran rebelión en los Andes: de Túpac Amaru a Túpac Catari. Cuzco: Centro de Estudios Regionales Andinos "Bartolomé de las Casas".

Peralta Ruiz, V. (1996). Tiranía o buen gobierno. Escolasticismo y criticismo en el Perú del Siglo XVIII (pp. 67-87). En Walker C. (comp.) Entre la retórica y la insurgencia: las ideas y los movimientos sociales en los Andes, Siglo XVIII, Cuzco: Centro de Estudios Regionales Andinos "Bartolomé de las Casas".

Ratio atque Institutio Studiorum Societatis Jesu. [1599] 1616 Auctoritate Septimae Congregationis Generalis aucta. Antverpiae apud Joan. Meursium, 1635, en $8^{\circ}$. (Reedición de la publicada en Roma en 1616). Traducción: Gustavo Amigó, S.J. La presente versión ha sido revisada por el Dr. Daniel Álvarez, S.J.

Rosas Lauro, C. (2009). Iglesia, evangelización e ilustración en el Perú del siglo de las Luces" (pp.139- 159). En: Armas Asín, F. La invención del catolicismo en América, los procesos de evangelización, siglos XVI-XVIII. Lima: Universidad Nacional Mayor de San Marcos. 
Serulnikov, S. (2003). Costumbres y reglas: racionalización y conflictos sociales durante la era borbónica (provincia de Chayanta, siglo XVIII) (pp. 77-133). En: A.A.V.V. 'Ya es otro tiempo el presente': Cuatro momentos de insurgencia indígena, La Paz: Muela del Diablo

Vargas Ugarte R. (1941). Historia de la Compañía de Jesús (1568-1767). Lima: Universidad Católica del Perú. 